\title{
TINJAUAN PROSES PERENCANAAN HERITAGE TRAILS SEBAGAI PRODUK PARIWISATA DALAM RIPPDA KOTA BANDUNG
}

\author{
Teguh Amor Patria \\ Hotel Management Department, Faculty of Economic and Communication, BINUS University \\ Jln. K. H. Syahdan No. 9, Palmerah, Jakarta Barat 11480 \\ tpatria@binus.edu
}

\begin{abstract}
Despite the fact that Bandung boasts a large number of heritage buildings as tourism potentials which become one of priorities in Rencana Induk Pengembangan Pariwisata Daerah (RIPPDA) Kota Bandung 20072016 (municipal tourism development plans), such plan is assumed as less detailed and comprehensive. It also emphasizes only on supply and spatial aspect. This paper reviewed the planning process of heritage trails as tourism product in the tourism development plan. A comparative study between actual and ideal condition was conducted and was presented in descriptive way. It consists of introduction, theoretical background relating to tourism product planning process and heritage tourism, research methodology, actual conditions of heritage trails development in Bandung, critical review of heritage trails in Bandung, and conclusion and recommendation. Such findings reveal the actual condition of heritage trails development as a growing tourism product in Bandung today, which lacks details, depth, and comprehensiveness, data from the past, and review from supply side in order to plan for a better heritage tourism activity.
\end{abstract}

Keywords: planning process, heritage trails, tourism product (TAP)

\begin{abstract}
ABSTRAK
Walaupun Kota Bandung memiliki bangunan pusaka (heritage buildings) dalam jumlah besar dan menjadi salah satu prioritas pengembangan dalam Rencana Induk Pengembangan Pariwisata Daerah (RIPPDA) Kota Bandung 2007-2016, perencanaannya masih dianggap kurang mendalam dan kurang komprehensif. Perencanaan pengembangan pariwisata pusaka di Bandung baru menyentuh permukaannya saja, serta lebih banyak menyentuh aspek supply dan aspek spasial. Artikel ini merupakan tinjauan terhadap proses perencanaan kegiatan heritage trails sebagai produk pariwisata dalam RIPPDA Kota Bandung. Studi komparatif antara kondisi aktual dan ideal dilakukan dan dipaparkan secara deskriptif yang terdiri dari pendahuluan, tinjauan teori berupa proses perencanaan produk pariwisata dan pariwisata pusaka (heritage tourism), kondisi aktual pengembangan heritage trails di Kota Bandung, metode penelitian, tinjauan kritis kondisi heritage trails di Kota Bandung, dan simpulan dan saran. Temuan adalah kondisi aktual perkembangan kegiatan heritage trails sebagai salah satu produk pariwisata yang berkembang di Kota Bandung dewasa ini, yang kurang dalam hal kerincian, kedalaman, dan menyeluruh, data dari masa lalu, dan tinjauan dari sisi sediaan untuk digunakan dalam perencanaan kegiatan pariwisata pusaka yang lebih baik.
\end{abstract}

Kata kunci: proses perencanaan, heritage trail, produk pariwisata (TAP) 


\section{PENDAHULUAN}

Perkembangan daya tarik wisata berbasis pusaka (heritage-base attractions) di tataran global telah menjadi hal yang fenomenal selama 1980-an dan 1990-an. Di banyak negara maju, pariwisata pusaka (heritage tourism) mendapat perhatian khusus untuk dikembangkan, salah satunya karena manfaat ekonomisnya. Sebagai contoh, pariwisata pusaka di Inggris telah meningkatkan volume pariwisata sebesar 5\% dan nilai keuntungan sebesar 10\% setiap tahun. Angka itu menunjukkan peningkatan 50\% jumlah pengunjung sejak 1980 dan menghasilkan keuntungan 3 juta Poundsterling.

Di kota Bandung, seperti di sejumlah kota besar lainnya di Indonesia, pariwisata pusaka merupakan fenomena yang baru berkembang pada awal milenium ini. Walaupun Bandung mewarisi banyak benda cagar budaya, terutama dari zaman keemasan pada 1920-an hingga awal 1940-an, pariwisata pusaka baru dikenal secara massal dengan dipicu oleh kehadiran kegiatan semacam heritage walk serta peran media massa sejak awal 2000-an.

Walaupun pusaka (heritage) menjadi salah satu prioritas pengembangan dalam Rencana Induk Pengembangan Pariwisata Daerah (RIPPDA) kota Bandung 2007-2016, dalam perencanaannya masih kurang mendalam dan kurang komprehensif. Perencanaan pengembangan pariwisata pusaka di Bandung baru menyentuh permukaannya saja, serta lebih banyak menyentuh aspek supply dan aspek spasial.

Berdasarkan latar belakang tersebut, artikel ini dibuat dengan tujuan untuk meninjau proses perencanaan heritage trails sebagai produk pariwisata di dalam RIPPDA kota Bandung periode 20072016.

\section{Tinjauan Literatur}

\section{Proses Perencanaan}

Perencanaan merupakan suatu kegiatan yang kompleks yang melibatkan banyak faktor dan dimensi waktu. Perencanaan, terutama yang menyangkut kepentingan publik, bukan merupakan kegiatan yang mempertimbangkan hanya satu aspek saja, seperti aspek sosial atau ekonomi atau politik atau lainnya, melainkan harus mengintegrasikan semua aspek dalam masyarakat. Perencanaan juga mempertimbangkan masa lalu dan masa kini untuk menentukan masa depan yang diinginkan. Hal tersebut ditegaskan oleh Rose dalam Gunn dan Var (2002) sebagai berikut, 'Planning is a multidimensional activity and seeks to be integrative. It embraces social, economic, political, psychological, anthropological, and technological factors. It is concerned with the past, present and future'.

Sehubungan dengan dimensi waktu yang disebutkan, perencanaan bercermin pada masa lalu serta mempertimbangkan masa kini untuk menentukan dan mencapai target masa mendatang. Oleh karena itu, dalam perencanaan harus terdapat arah dan langkah-langkah yang harus dilalui untuk mencapai target yang telah ditentukan. McCabe dalam Mason (2003) menjabarkan hal tersebut, 'A plan ... enables us to identify where we are going and how to get there (emphasis added) - in other words it should clarify the path that is to be taken and the outcomes or end results. It also draws attention to the stages on the way and ... helps to set and establish priorities that can assist in the scheduling of activities'.

Perencanaan juga dilihat sebagai sebuah proses yang terdiri dari berbagai elemen. Salah satu elemen dalam proses perencanaan adalah pengambilan keputusan (Veal, 1994; Hall, 2000). Veal (1994:3) menyatakan bahwa 'perencanaan dapat dilihat sebagai proses pengambilan keputusan'. Hall 
(2000a) menawarkan pemikirannya bahwa keputusan-keputusan ini saling bergantung satu sama lain serta terkait secara sistematis. Proses perencanaan menyangkut 'bargaining, negotiation, compromise, coercion, values, choice and politics' (Hall dalam Mason, 2003). Pemikiran lain ditawarkan oleh Chadwick dalam Mason (2003) yang menyebutkan bahwa 'planning is a process, a process of human thought and action based upon that thought - in point of fact, forethought, thought for the future, nothing more or less than this is planning'.

Seperti perencanaan dalam konteks umum, perencanaan dalam konteks kepariwisataan juga tidak terlepas dari kepentingan publik. Hal ini dikarenakan sifat kepariwisataan sebagai suatu industri yang melibatkan banyak pihak terkait dari banyak sektor. Dengan keterlibatan banyak pihak dan banyak sektor, perencanaan kepariwisataan harus mempertimbangkan nilai-nilai yang diyakini oleh para pihak terkait dari berbagai sektor. Healey dalam Mason (2003) mengindikasikan bahwa kebijakan publik dan perencanaan merupakan 'social process through which ways of thinking, ways of valuing and ways of acting are actively constructed by participants'. Pemikiran itu juga didukung juga oleh Gunn (1998) dan Veal (1994) yang menyatakan bahwa perencanaan untuk rekreasi dan kepariwisataan sangat bergantung pada nilai-nilai (values), dan masing-masing berargumentasi bahwa nilai-nilai komunitas (community values) betul-betul penting. Oleh karena itu, kebijakan rekreasi dan/atau kepariwisataan harus mencerminkan nilai-nilai pihak-pihak terkait (stakeholders).

Dua puluh tahun yang lalu, tujuan utama perencanaan kepariwisataan disimpulkan sebagai berikut: 'to ensure that opportunities are available for tourist to gain enjoyable and satisfying experiences and at the same time to provide a means for improving the way of life for residents and of destination areas' (Matthieson dan Wall dalam Mason, 2003). Pemikiran itu menekankan bahwa perencanaan kepariwisataan harus mampu menaikkan kualitas pengalaman wisatawan serta kualitas hidup masyarakat dan lingkungan daerah tujuan wisata. Dalam perkembangannya hingga dewasa ini, beberapa point penting ditambahkan (Williams dalam Mason, 2003), yaitu: menciptakan mekanisme penyediaan fasilitas yang terstruktur di wilayah geografis yang cukup luas; mengoordinasikan elemenelemen pariwisata (terutama yang berhubungan dengan akomodasi, transportasi, pemasaran dan sumber daya manusia); melibatkan secara khusus aspek pelestarian sumber daya dan memaksimalkan manfaat-manfaatnya bagi masyarakat lokal dalam upaya mencapai keberlanjutan (biasanya melalui suatu pengembangan kepariwisataan atau rencana manajemen); mendistribusikan kembali manfaatmanfaat pariwisata (pengembangan situs-situs pariwisata baru atau mengembalikan kondisi ekonomi tempat-tempat yang sudah mulai ditinggalkan wisatawan).

Hall dalam Page dan Connell (2006) menyatakan bahwa perencanaan adalah sebuah proses yang bertujuan untuk mengantisipasi, mengatur, dan memonitor perubahan agar dapat berkontribusi secara lebih luas terhadap keberlanjutan destinasi, sehingga dapat meningkatkan pengalaman wisatawan terhadap destinasi atau tempat tersebut. Bagan berikut memperlihatkan langkah-langkah dalam perencanaan kepariwisataan. 


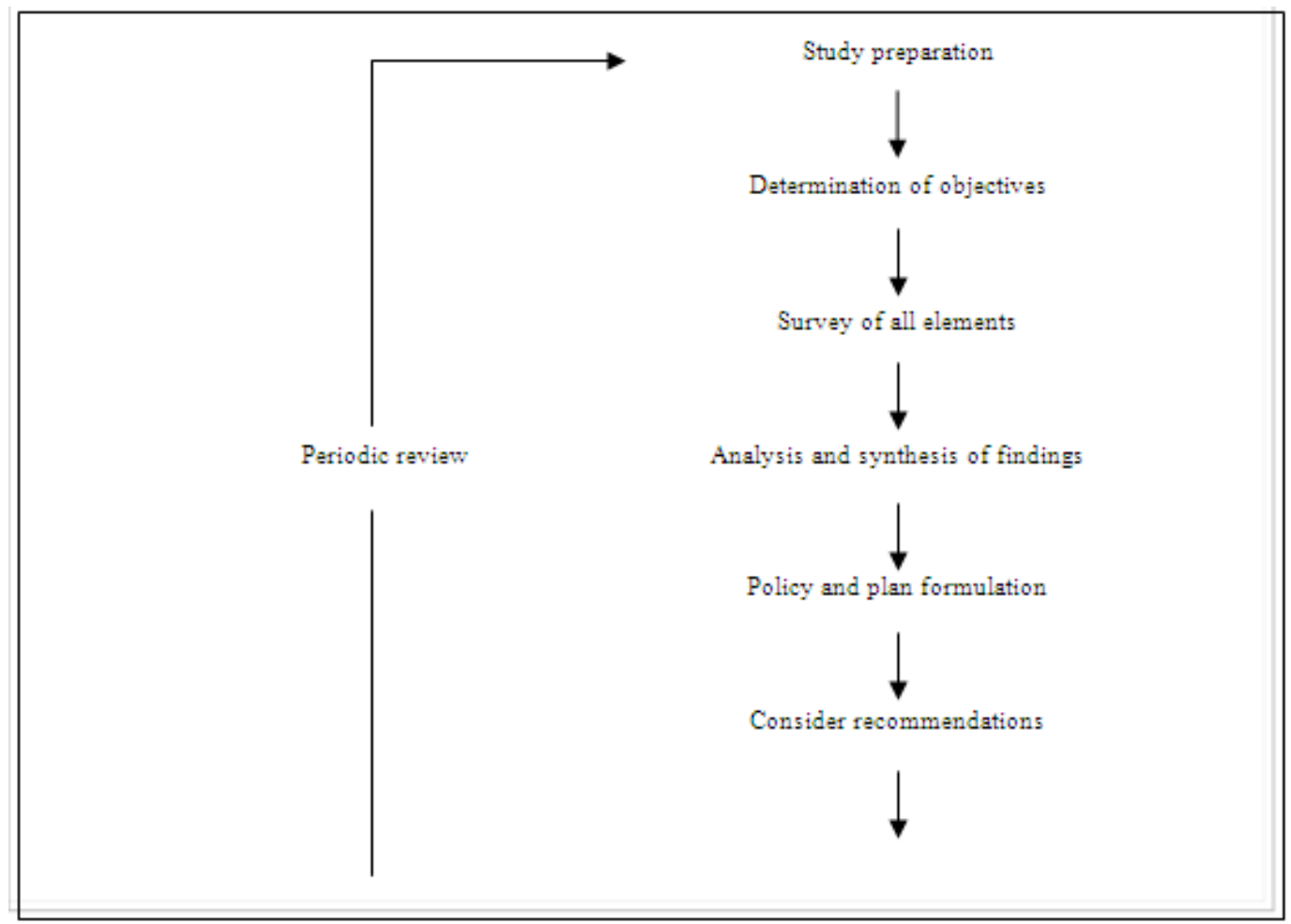

Gambar 1 Langkah-langkah dalam Perencanaan Kepariwisataan (Sumber: Page and Connell, 2006)

Dalam prosesnya, perencanaan kepariwisataan melibatkan elemen-elemen kepariwisataan seperti daya tarik dan kegiatan wisatawan, akomodasi, tranportasi, elemen-elemen institusional, prasarana lain, dan sarana dan pelayanan lainnya bagi wisatawan. Page dan Thorn dalam Page dan Connell (2006) membagi perencanaan menjadi tiga tingkatan umum, yaitu nasional (contoh negara), regional (contoh propinsi atau kabupaten), dan lokal (contoh kota, distrik, atau lokalitas). Sedangkan Gunn dan Var (2002) membaginya menjadi skala situs (site), destinasi (destination), dan wilayah (regional).

\section{Produk Pariwisata}

Teori-teori kepariwisataan secara umum membagi produk pariwisata menjadi tiga bagian besar, yaitu daya tarik wisata, aksesibilitas, dan amenitas. Namun beberapa teori menyatakan bahwa daya tarik wisata adalah produk pariwisata yang utama, sedangkan aksesibilitas dan amenitas merupakan produk ikutan atau sampingan. Tanpa daya tarik wisata, aksesibilitas dan amenitas tidak akan ada atau tidak dapat disebut produk pariwisata. Lebih jauh lagi, beberapa teori membagi daya tarik pariwisata menjadi daya tarik wisata dan industri kepariwisataan (tourism industry).

Pemahaman tersebut ditegaskan oleh Weaver dan Lawton (2006) yang mendefinisikan 'produk pariwisata' sebagai 'the combination of tourist attractions and the tourism industry'. Daya tarik wisata (tourist attractions) adalah komponen utama dari suatu destinasi, sedangkan komponenkomponen lainnya, yang tergabung dalam tourism industry, mencakup agen perjalanan wisata, transportasi, akomodasi, operator tur, dan merchandise. Daya tarik pariwisata (attraction) didefinisikan secara operasional oleh Pearce dalam Page dan Connell (2006) sebagai berikut, 'A tourist attraction is a named site with a specific human or natural feature which is the focus of visitor and management attention'. Dari definisi tersebut dapat dipahami bahwa daya tarik wisata adalah objek berbasis sumber daya budaya atau alam yang memiliki nilai-nilai yang menarik perhatian 
pengunjung dan manajemen. Daya tarik wisata biasanya merupakan suatu unit individual, dan hal ini yang membedakannya dari destinasi yang biasanya merupakan satuan wilayah yang memiliki satu atau lebih daya tarik wisata. Swarbrooke (2002:9) menekankan perbedaan antara daya tarik wisata dengan destinasi wisata sebagai berikut, 'Attractions are generally single units, individual sites or very small, easy delimited geographical areas based on a single key feature. Destinations are larger areas that include a number of individual attractions together with the support services required by tourist'.

Daya tarik wisata (attractions) di suatu destinasi merupakan komponen dari sisi sediaan pariwisata yang paling kuat. Jika pasar (wisatawan) merupakan faktor push, daya tarik wisata merupakan faktor pull-nya. Di antara pasar dan daya tarik wisata terdapat usaha pelayanan yang berfungsi sebagai fasilitator. Daya tarik wisata memiliki dua fungsi 'first, they entice and stimulate interest in travel. Second, attractions provide visitor satisfactions, the rewards from travel - the true travel "product".

Gunn dan Var mengurai beberapa hal yang harus dipertimbangkan dalam perencanaan daya tarik wisata, yaitu: (1) daya tarik diciptakan dan dikelola, artinya suatu objek tidak dapat berfungsi sebagai daya tarik dan tidak bisa dipromosikan sebelum diidentifikasi, dirancang, didirikan, dan dikelola untuk pengunjung; (2) daya tarik dapat dicapai melalui pengelompokan tema, baik secara fisik maupun melalui tur, contoh garden tours, historic tours, architectural tours, dan pelayaran (cruise); (3) penghubungan antara daya tarik dan pelayanan penting sifatnya karena daya tarik memerlukan dukungan dari pelayanan perjalanan (travel services); (4) daya tarik bisa mencakup skala perdesaan atau perkotaan karena pasar menyukai suasana dan pengalaman perdesaan maupun perkotaan. Gunn dan Var membagi klasifikasi daya tarik berdasarkan tiga kelompok, yaitu menurut kepemilikan (by ownership), menurut sumber daya (by resource), dan menurut lama tinggal (touring/long stay). Berikut adalah tabel tentang klasifikasi menurut Gunn dan Var tersebut.

Tabel 1 Classification of Attractions by Ownership

\begin{tabular}{lll}
\hline Governments & Nonprofit Organizations & Business Sector \\
\hline National parks & Historic sites & Theme parks \\
State parks & Festivals & Cruises \\
Wildlife reserves & Organization camps & Shopping centers \\
Scenic/historic roads & Elderhostels & Specialty food \\
Recreation areas & Historic architecture & Resorts \\
National monuments & Theaters & Golf courses \\
Wildlife sanctuaries & Gardens & Theaters \\
Zoos & Museums & Craft shops \\
Bike/hike trails & Parades & Plant tours \\
Sports arenas & Nature reserves & Race tracks \\
\hline
\end{tabular}

(Sumber: Gunn dan Var, 2002)

Tabel 2 Classification of Attractions by Resource

\begin{tabular}{ll}
\hline Natural Resources Foundation & Cultural Resources Foundation \\
\hline Beach resorts & Historic sites \\
Campgrounds & Archeological sites \\
Parks & Museums \\
Ski resorts & Ethnic areas \\
Cruises & Festivals \\
Golf courses & Medical centers \\
Nature reserves & Trade centers \\
Organization camps & Theaters \\
Bike/hike trails & Plant tours \\
Scenic roads & Convention centers \\
\hline
\end{tabular}


(Sumber: Gunn and Var, 2002)

Tabel 3 Classification of Attractions by Touring/Long Stay

\begin{tabular}{ll}
\hline Touring & Long Stay \\
\hline Roadside scenic areas & Resorts \\
Natural areas & Organization campsites \\
Historic buildings, sites & Vacation home complexes \\
Specialty food places & Gaming centers \\
Shrines & Dude ranches \\
Zoos & Convention centers \\
\hline
\end{tabular}

(Sumber: Gunn and Var, 2002)

Dewasa ini, beberapa segmen pasar perjalanan makin mencari destinasi dengan sumber daya budaya yang besar. Kategori sumber daya budaya mencakup situs-situs prasejarah; situs-situs sejarah; tempat-tempat etnis, cerita rakyat, edukasi; industri, pusat-pusat perdagangan, pusat-pusat profesional; tempat-tempat pertunjukan kesenian, museum, galeri; dan situs-situs yang penting untuk hiburan, kesehatan, olahraga, dan agama. Berikut adalah tabel yang mendeskripsikan tentang pengembangan kepariwisataan terkait sumber daya budaya.

Tabel 4 Tourism Development Related to Cultural Resources

\begin{tabular}{|c|c|}
\hline Resource & Typical Development \\
\hline Prehistory, Archeology & $\begin{array}{l}\text { Visitor interpretive centers, archeological digs, prehistory parks and preserves, } \\
\text { nautical archeological sites, festival sites related to prehistory, exhibits and } \\
\text { customs to prehistory }\end{array}$ \\
\hline History & $\begin{array}{l}\text { Historic sites, historic architecture, historic shrines, museums depicting eras of } \\
\text { human history, cultural centers, historic pageants, festivals, landmarks, historic } \\
\text { parks }\end{array}$ \\
\hline $\begin{array}{l}\text { Ethnicity, Lore, } \\
\text { Education }\end{array}$ & $\begin{array}{l}\text { Places important to legends and lore, places of ethnic im } \\
\text { foods, dress, beliefs), ethnic and national cultural cente } \\
\text { dude ranches, gardens, elder hostels, universities }\end{array}$ \\
\hline $\begin{array}{l}\text { Industry, T } \\
\text { Profession }\end{array}$ & $\begin{array}{l}\text { Manufacturing and processing plants, retail and wholesale businesses, } \\
\text { conference centers, educational and research institutions, convention centers, } \\
\text { performing arts, museums, galleries }\end{array}$ \\
\hline $\begin{array}{l}\text { Entertainment, Health, } \\
\text { Religion, Sports }\end{array}$ & $\begin{array}{l}\text { Spas, health centers, fitness resorts, health specialty restaurants, religious } \\
\text { meccas, shrines, sports arenas, night clubs, gaming casinos, theatres, museums } \\
\text { (history, art, natural history, applied science, children's folk), art galleries }\end{array}$ \\
\hline
\end{tabular}

(Sumber: Gunn and Var, 2002)

Penguraian lainnya dilakukan oleh Timothy dan Dallen dengan mengadaptasi jenis-jenis daya tarik pusaka yang dilakukan oleh Prentice (1994) berikut.

Tabel 5 Jenis-jenis Daya Tarik Pusaka

\footnotetext{
Natural history attractions - nature preserves, nature trails, aquatic displays, wildlife parks, zoos, caves, gorges, cliffs, waterfalls

Scientific attractions - science museums, technology centres, 'hands-on' science centres

Primary production attractions - farms, dairies, agricultural museums, vineyards, fishing, mining

Craft centres and workshops - water and windmills, sculptors, potters, woodcarvers, metal shops, glass makers, silk working, lace making, craft villages

Manufacturing centres - pottery and porcelain factories, breweries, cider factories, distilleries, industrial history museums

Transportation attractions - transport museums, railways, canals, shipping and docks, civil aviation, motor vehicles
} 


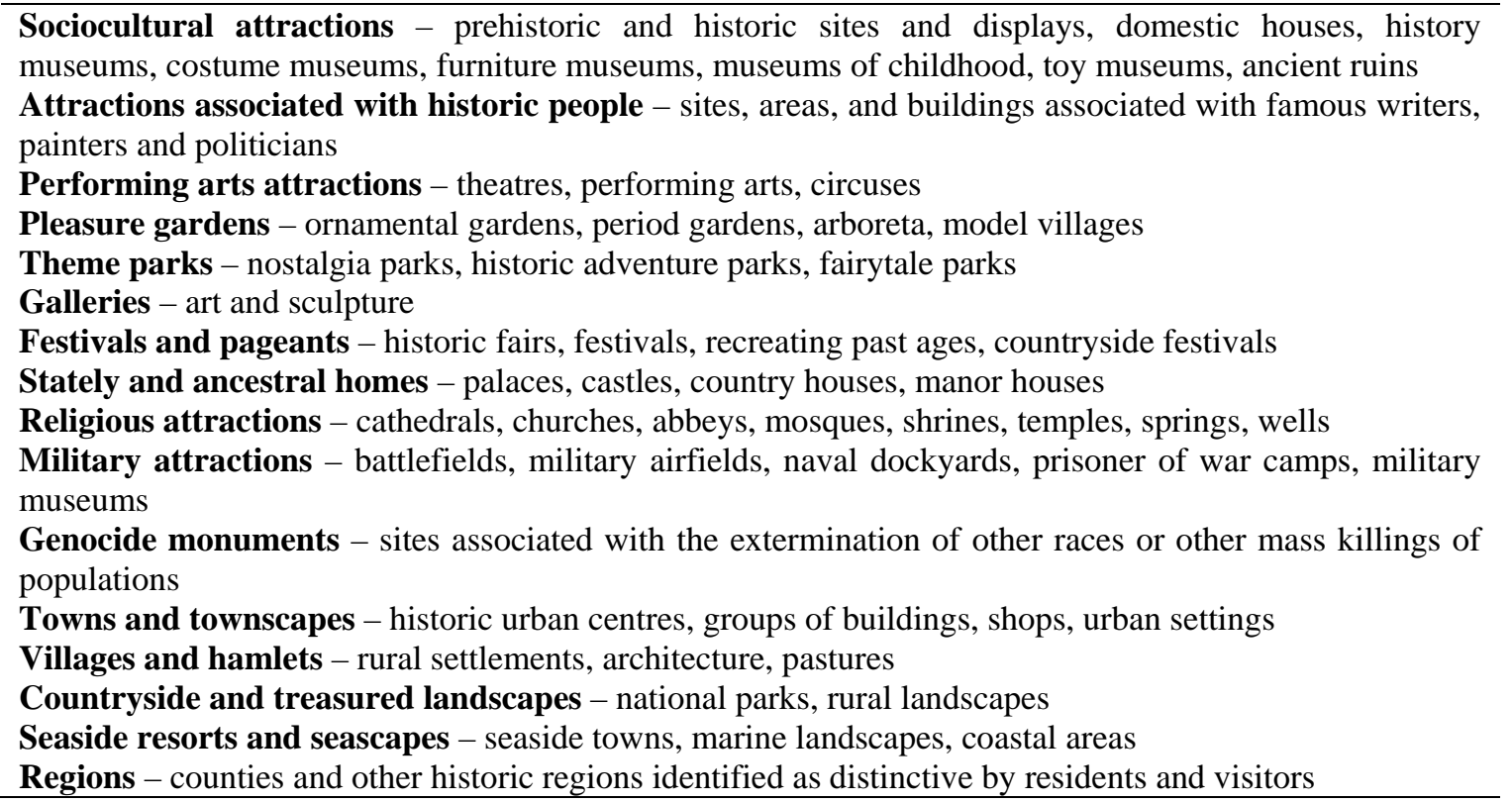

(Sumber: diadaptasi oleh Timothy dan Boyd dari Prentice, 1994)

\section{Heritage Trails}

Pusaka (heritage) secara umum diartikan sebagai warisan. Di Indonesia, istilah 'pusaka' mulai digunakan pada 2004, bersamaan dengan peresmian Badan Pelestarian Pusaka Indonesia (BPPI) di Jakarta. Drummond dan Yeoman (2001) mengurai pengertian pusaka sebagai berikut, 'A simple definition of heritage is what is or may be inherited - this can include traditions, values, historical events, industrial machinery from a bygone era, historic houses, art collections, cultural activities and natural riches such as beaches, mountains, flora and fauna. This definition encompasses a myriad of attractions and activities upon which to build a lucrative tourist industry and it is therefore not surprising that many destinations are discovering or rediscovering their heritage.

Objek pusaka telah menjadi daya tarik sejak manusia melakukan perjalanan ribuan tahun yang lalu. Pariwisata pusaka (heritage tourism) modern mulai berkembang abad ke-16 di Eropa, ketika aristokrat muda Inggris melakukan perjalanan ke kota-kota klasik di Eropa Daratan. Kegiatan itu dikenal sebagai Grand Tour. Dalam perkembangannya, pariwisata pusaka berkembang ke Dunia Baru dan menyentuh semua kalangan. Produk-produk pariwisata pusaka dalam perkembangannya kerap menghubungkan antara satu objek pusaka dengan lainnya, membentuk satu rute yang biasanya memiliki satu tema tertentu. Hal itu dikenal sebagai heritage trails atau jejak pusaka.

Menurut NSW Heritage Office (1995), heritage trails adalah “... established routes linking significant items of an area's heritage. They are usually promoted in tourist pamphlets and are often supplemented by interpretive pamphlets or cassette tapes. Some trails incorporate plaques or signs on particular structures to provide additional information." Sedangkan pemahaman heritage trails lainnya dilakukan oleh Timothy dan Boyd (2003) sebagai berikut: "In all cases, the primary physical characteristic of heritage trails is their linear and nodal properties. In most cases, they are a composition of specific individual attractions connected by a walking, cycling and/or driving route."

Sebagai tambahan, Timothy dan Boyd juga menyebutkan:

"Heritage trails are unique in context in that they can encompass both urban and rural areas, and sometimes a combination of the two. Broadly speaking, it is possible to argue that the setting in which mega and large-scale trails are found is predominantly rural with a certain 
urban component, whereas small-scale trails are almost exclusively found within urban areas. In terms of their subject matter, while each trail offers a specific theme and tells a different story, in general terms it is possible that most mega and large-scale trails focus on pilgrimage and/or religious history, migration and trade routes, connected urban centres, or observation of the natural heritage of the region. In contrast, small-scale trails are specifically theme driven, including industrial, cultural and literary heritage, to name a few."

Selanjutnya juga dijelaskan a heritage trail can be explored as a guided tour or in self-guided form. Guided tours, which are generally walking tours or bus tours, and which usually charge a fee, cater only for visiting groups or organized party excursions. A knowledgeable guide can add significantly to the participants' appreciation of the tour and of the items visited. Guided tours are a very good way for visitors with a limited amount of time to be given a good overview of a locality's heritage. They can also add a bonus by enabling the group to inspect properties which are otherwise inaccessible from the street.

NSW Heritage Office kemudian menjabarkan beberapa manfaat pengembangan heritage trails, yang mencakup: meningkatkan kesadaran akan pusaka lokal dan menstimulasi minat terhadap pelestarian, mempromosikan sejarah kawasan kepada pengunjung, mensosialisasikan kegiatan pelestarian yang signifikan, dan menyediakan suatu pengalaman ekskursi yang sudah jadi dan bersifat rekreatif dan edukatif. Selanjutnya dijelaskan juga bahwa heritage trails biasanya memiliki target pengguna yang spesifik, bersifat tematik, dan mengangkat ikon (icon) sebuah destinasi. Hal itu ditegaskan sebagai berikut:

"To help achieve these objectives, you will need to clearly specify the aims of the heritage trail and any specific user groups to be targeted, as this will have a significant bearing on the items to be included. Many tours feature the heritage "icons" of the area and representative samples of particular architectural periods and types. A thematic approach, however, can be better suited to particular interest groups or areas. Possible themes include architectural styles, e.g. art deco; features, e.g. stained glass windows or leadlights; industrial heritage; underwater heritage; significant people, or historical processes or events."

Dalam merancang sebuah heritage trails, diperlukan langkah-langkah berikut. Langkah 1 menentukan fokus trail dan identifikasi kelompok sasaran utamanya. Langkah 2 mengumpulkan daftar hal-hal yang mungkin untuk dimasukkan ke dalam sebuah heritage trail. Langkah 3 mempersiapkan sebuah rute rancangan yang menghubungkan tempat-tempat terpilih yang menarik dalam sejarah. Langkah 4 mengkaji kecocokan tempat-tempat yang dinominasikan.

\section{METODE PENELITIAN}

Artikel ini didasarkan pada penelitian kualitatif. Masyuri dan Zainuddin (2009) mendefinisikan penelitian kualitatif sebagai penelitian yang melibatkan data empiris dalam penyelesaian masalahnya. Dalam penelitian ini, penyelesaian masalah atau saran didasarkan pada hasil studi komparatif antara kondisi aktual (RIPPDA Kota Bandung 2007-2016) dan kondisi ideal (teoretis tentang perencanaan produk pariwisata dan heritage trails). 


\section{HASIL DAN PEMBAHASAN}

\section{Heritage Trails di Kota Bandung}

\section{Proses Perencanaan}

Pengembangan kepariwisataan di Kota Bandung, termasuk produk pariwisatanya, mengacu pada Rencana Induk Pengembangan Pariwisata Daerah (RIPPDA). RIPPDA Kota Bandung merupakan rencana strategis sektoral yang disusun untuk kepariwisataan Kota Bandung. RIPPDA Kota Bandung merupakan bagian dari Rencana Pembangunan Jangka Panjang (RPJP) tingkat nasional. Pada tingkat di bawahnya, RPJP menghasilkan Rencana Panjang Jangka Menengah (RPJM). RPJM terbagi menjadi dua bagian, yaitu rencana strategis yang sifatnya sektoral (untuk pengembangan sektor-sektor yang menjadi tanggung jawab kementerian yang ada di Republik Indonesia) dan rencana strategis yang sifatnya institusional (untuk pengembangan badan dan organisasi masing-masing kementerian). Baik rencana strategis yang bersifat sektoral maupun institusional memiliki tingkatan mulai nasional, propinsi, kabupaten/kota, dan pada beberapa kasus, satuan skala yang lebih kecil.

RIPPDA Kota Bandung terkini disusun pada 2006 untuk jangka waktu 10 tahun (2007 sampai dengan 2016). Sesuai namanya, RIPPDA Kota Bandung merupakan rencana strategis sektoral di bidang kepariwisataan untuk skala kota (Bandung). Dalam RIPPDA Kota Bandung ditentukan prioritas pengembangan sumber daya pariwisata berdasarkan tingkat kepentingan dan kemampuan sumber daya, serta pertimbangan resiko yang dihadapi. Secara operasional, RIPPDA berfungsi sebagai pedoman dasar pembangunan kepariwisataan bagi pemerintah, sektor bisnis pariwisata, dan masyarakat pada masa yang akan mendatang.

Visi Kota Bandung adalah Kota Jasa yang BERMARTABAT (Bersih, Makmur, Taat, Bersahabat). Pemerintah Kota Bandung juga berketetapan menjadikan pariwisata sebagai salah satu paradigma baru pembangunan dengan sasaran salah satunya untuk meningkatkan Pendapatan Asli Daerah (PAD) dalam wujud pengembangan yang berkelanjutan (sustainable tourism development). Hal itu tercantum dalam tujuan bidang sosial dan budaya, khususnya butir tentang Kebudayaan, Kesenian, dan Pariwisata (RENSTRA Kota Bandung 2004 - 2008).

Pertimbangan pengembangan pariwisata di Kota Bandung didasarkan pada beberapa kondisi, seperti 1) Kota Bandung merupakan salah satu destinasi wisata unggulan Provinsi Jawa Barat, 2) Perkembangan pariwisata Kota Bandung ditopang oleh ketersediaan dan variasi produk wisata perkotaan, pendidikan, sejarah, dan budaya yang didukung oleh prasarana dan sarana pariwisata yang memadai, 3) Kota Bandung didukung oleh wilayah sekitarnya yang bercirikan wisata alam, yang dapat menjadi daya tarik baik bagi wisatawan nusantara dan mancanegara, 4) Kota Bandung memiliki kapasitas sebagai pusat distribusi (point of distribution) bagi destinasi wisata lainnya di Jawa Barat, serta 5) perkembangan sarana wisata perkotaan yang menjadi daya tarik kuat bagi Kota Bandung.

Latar belakang hukum penyusunan RIPPDA Kota Bandung adalah: 1) Undang-Undang No. 32 Tahun 2004 tentang Pemerintahan Daerah (Lembaran Negara Tahun 2004 Nomor 125, Tambahan Lembaran Negara Nomor 4437), 2) Undang-Undang No. 9 Tahun 1990 tentang Kepariwisataan, 3) Peraturan Pemerintah No. 67 Tahun 1996 tentang Penyelenggaraan Kepariwisataan, 4) Peraturan Daerah Kota Bandung No. 02 Tahun 2001 tentang Kewenangan Daerah Kota Bandung sebagai Daerah Otonom, 5) Peraturan Daerah Kota Bandung No. 06 Tahun 2004 tentang Rencana Strategi (Renstra) Kota Bandung Tahun 2004-2008, dan 6) Peraturan Daerah Kota Bandung No. 03 Tahun 2006 tentang Rencana Tata Ruang Wilayah (RTRW) Kota Bandung.

Penyusunan RIPPDA Kota Bandung dimaksudkan untuk memberikan pedoman arah terhadap tujuan pengembangan pariwisata di Kota Bandung, dengan penyesuaian pada paradigma baru 
pembangunan pariwisata, sistem otonomi daerah, dan perkembangan destinasi serta pasar wisata. Tujuan dari penyusunan RIPPDA Kota Bandung adalah merancang sebuah Rencana Induk Pengembangan Pariwisata Kota Bandung yang komprehensif, terpadu, berkelanjutan, dan berdaya saing dengan memanfaatkan potensi yang ada, yang dapat digunakan sebagai pedoman dalam penyusunan rencana aksi dan kegiatan kepariwisataan di bawahnya; keberkelanjutan yang dimaksud adalah baik secara kultur dan lingkungan, pemanfaatan secara spasial, maupun secara sektoral.

Keluaran yang diharapkan dari penyusunan RIPPDA Kota Bandung antara lain 1) memberikan gambaran potensi yang dimiliki serta identifikasi kendala-kendala yang ada, 2) menyediakan media bagi keterpaduan lintas sektoral guna melancarkan pelaksanaan penyelenggaraan urusan pengembangan kepariwisataan, dan 3) memberikan gambaran kepada masyarakat luas dan stakeholders tentang partisipasi dalam pengembangan kepariwisataan.

Ruang lingkup penyusunan RIPPDA Kota Bandung meliputi 1) identifikasi awal; isu-isu strategis (masalah, tren, paradigma), 2) identifikasi dan inventarisasi destinasi wisata, 3) menganalisis potensi pariwisata yang meliputi produk wisata, SDM, hubungan antar stakeholders, dan pasar dan pemasaran, 4) menyempurnakan/memantapkan Visi dan Misi Pariwisata Kota Bandung, 5) menyusun arahan strategi pengembangan kepariwisataan meliputi pengembangan produk wisata, SDM, hubungan antar-stakeholders, serta pasar dan pemasaran pariwisata, 6) menyusun indikasi Program Pengembangan Kepariwisataan, dan 7) Penyusunan Draft Peraturan Hukum (legalitas) RIPPDA.

\section{Produk Wisata}

Dalam Bab 2 RIPPDA Kota Bandung, disebutkan bahwa salah satu potensi pariwisata Kota Bandung adalah wisata heritage. Berdasarkan kemampuan sumber daya pariwisata dan pola pengembangan kawasan kota, maka citra produk pariwisata di Kota Bandung dapat diklasifikasikan sebagai destinasi wisata spesifikasi urban tourism dengan variasi potensi daya tarik dan aktivitas wisata alam, budaya, buatan, dan kegiatan khusus (special event) serta kombinasi di antaranya. Di bawah payung destinasi urban tourism sebagai main tourist attraction, Kota Bandung memiliki karakteristik produk pariwisata perkotaan dengan tipologi. Hal itu dapat dilihat pada tabel berikut.

Tabel 6 Tipologi Potensi Atraksi Wisata Perkotaan

\begin{tabular}{cl}
\hline No & \multicolumn{1}{c}{ Tipologi Potensi Atraksi Wisata Perkotaan } \\
\hline a. & Wisata Heritage (Wisata Peninggalan Bersejarah / Wisata Pusaka) \\
b. & Wisata Belanja dan Kuliner \\
c. & Wisata Pendidikan \\
d. & Rekreasi dan Hiburan (alam, budaya dan buatan) \\
e. & MICE (meeting, incentive, convention and exhibition) \\
\hline
\end{tabular}

(Sumber: RIPPDA Kota Bandung 2007-2016)

Wisata heritage di Kota Bandung didominasi oleh pengaruh peninggalan budaya asing akibat masa penjajahan, misionaris keagamaan serta perdagangan yang membentuk keunikan karakter fungsi dan tata ruang Kota Bandung. Potensi produk wisata yang dapat dikembangkan dalam bentuk wisata heritage adalah pengemasan produk wisata ke dalam bentuk paket-paket wisata dalam kota yang menawarkan kegiatan-kegiatan nostalgia, pendidikan, dan belanja. Lokus potensi pengembangan kawasan wisata heritage di Kota Bandung adalah kawasan-kawasan yang masih memiliki nilai-nilai sejarah kolonial dan Pecinan yang masih mendominasi karakteristik fisik bangunan dan sosial budaya masyarakat Kota Bandung. Kawasan-kawasan tertentu di Kota Bandung yang memiliki nilai-nilai heritage kolonial dan Pecinan adalah Kawasan Pemerintahan dan Perkantoran (Asia Afrika-BragaCikapundung), Kawasan Militer (Gedung Kodam Siliwangi-Jalan Aceh), Kawasan Pemukiman (Cipaganti-Dago-Riau), dan Kawasan Perdagangan (Otista-Gardu Jati). 
Citra kawasan heritage Kota Bandung yang terkenal dengan sebutan Paris Van Java, Bandung Tempo Doeloe, dan Bandung Lautan Api merupakan potensi lama yang perlu digali dan direncanakan pengembangannya dalam upaya melestarikan nilai sejarah Kota Bandung sebagai kota wisata heritage. Tantangan dalam pengembangan potensi kawasan wisata heritage ini adalah harus tetap mempertahankan fungsi tata ruang kawasan Kota Bandung dalam upaya melestarikan bangunanbangunan lama terhadap kepentingan komersial yang bersifat sesaat dengan merubah peruntukan lahan tata ruang wilayah seperti yang terjadi perubahan fungsi kawasan pemukiman menjadi kawasan perdagangan seperti factory outlet. Selain itu, peningkatan terhadap sarana informasi dan interpretasi sebagai penunjang kegiatan wisata heritage sangat diperlukan dalam upaya memahami nilai-nilai sejarah yang terkandung di dalamnya yang mampu menambah kualitas pengalaman berwisata.

Strategi pengembangan produk wisata Kota Bandung diarahkan untuk memiliki karakter Urban Heritage Tourism dengan lingkungan yang sejuk, hijau, dan berbunga. Dari 15 kantong pengembangan kawasan wisata hasil pengelompokan dan pentemaan di Kota Bandung, terdapat 5 kantong yang memuat unsur heritage, yaitu:

Tabel 7 Kantong Kawasan Wisata Cihampelas - Cipaganti

\begin{tabular}{ll}
\hline Tema & Cihampelas Shopping Arcade \\
\hline Atraksi Wisata & Pusat Perbelanjaan (Ciwalk Mall, Pusat Konveksi dan Jins Cihampelas), \\
& Swalayan (Premier), Restaurant \& Café, Fast Food, Bakery Shop, Toko \\
& Oleh-Oleh Khas Bandung, Aktivitas Pinggir Jalan (Distro, Pedagang Kaki \\
& lima) Factory Outlet, Rencana pembangunan pusat perdagangan elektronik \\
& (Cihampelas Electronic Center/bekas sultan plaza), Hiburan/entertainment \\
& (Discotik Studio East), Perumahan-Perumahan Peninggalan Belanda \\
Aktivitas Wisata & Wisata Belanja \& Kuliner - Wisata Heritage \\
\hline
\end{tabular}

(Sumber: RIPPDA Kota Bandung 2007-2016)

Tabel 8 Kantong Kawasan Wisata Alun-alun - Sudirman - Otista - Gardujati - Pasirkaliki

\begin{tabular}{ll}
\hline Tema & Alun-Alun Tourist-Entertainment complexes \\
\hline Atraksi Wisata & Kawasan Alun-alun (Mesjid Agung, Pusat Perbelanjaan, Kompleks \\
& Alun-alun, Taman Alun-Alun), Pusat Kantor Pos Bandung, Pub- \\
& Diskotik-Karoke Jl. Jend. Sudirman, Pusat Perbelanjaan (Pertokoan \\
& Pasar Baru \& Jl. ABC, Pasar Baru Trade Center, Pascal Hypermart, \\
& Istana Plaza) \\
& Wisata Belanja \& Kuliner - Wisata Hiburan \& Rekreasi - Wisata \\
Aktivitas Wisata & Heritage - Wisata Religi \\
\hline
\end{tabular}

(Sumber: RIPPDA Kota Bandung 2007-2016)

Tabel 9 Kantong Kawasan Wisata Gedung Sate-Gasibu-Sabuga

\begin{tabular}{ll}
\hline Tema & Bandung Landmark City \\
\hline Atraksi Wisata & Bangunan Peninggalan Bersejarah (Gedung Sate, Villa Merah), \\
& Institusi/lembaga pendidikan dan museum (ITB, Universitas Padjajaran, \\
& Museum Geologi), Tempat Peribadatan (Mesjid Salman, Istiqomah, \\
& PUSDAI), Taman Wisata Alam dan Rekreasi (Kebon Binatang, TWA \\
& Babakan Siliwangi), Wisata Buatan (Sabuga Convention Hall, Lapangan \\
& Gazibu, Monumen Perjuangan.) \\
Aktivitas Wisata & Wisata Heritage - Wisata Pendidikan - Wisata Rekreasi Alam \& Buatan - \\
& Wisata Konvensi (MICE) - Wisata Religi \\
\hline
\end{tabular}

(Sumber: RIPPDA Kota Bandung 2007-2016) 
Tabel 10 Kantong Kawasan Wisata Braga - Asia Afrika - Cikapundung

\begin{tabular}{ll}
\hline Tema & Bandung Historic Center \\
\hline Atraksi Wisata & Pusat Perbelanjaan (Kawasan Pertokoan Sepanjang Jl. Braga, \\
& Braga City Walk), Restauran \& Café, Bakery Shop, Pertokoan \\
& Asesoris Kendaraan Jl. Cikapundung, Pub, Karoke, Diskotik di \\
& Kawasan Braga, Sungai Cikapundung dan sekitarnya, \\
& Peninggalan Bangunan Sejarah Belanda Kawasan Asia Afrika \\
& (Gedung Merdeka, Kantor -kantor), Hotel-hotel bernilai \\
& sejarah (Savoy Homan, Preanger) \\
& Wisata Heritage - Wisata Belanja - Wisata Konvensi (MICE) \\
\hline
\end{tabular}

(Sumber: RIPPDA Kota Bandung 2007-2016)

Tabel 11 Kantong Kawasan Wisata Gatot Subroto - Binong Jati

\begin{tabular}{ll}
\hline Tema & Gatsu Small Fortress Complex \\
\hline Atraksi Wisata & Kompleks pertahanan militer (Kompleks Kavaleri/Kodam \\
& Gatot Subroto), Pusat Perbelanjaan dan Rekreasi (Bandung \\
& Super Mall) Fast Food, Restaurant \& Bakery Shop, Pusat \\
& Kerajinan Rajutan Binong Jati. \\
Aktivitas Wisata & Wisata Heritage - Wisata Belanja \& Kuliner \\
\hline
\end{tabular}

(Sumber: RIPPDA Kota Bandung 2007-2016)

\section{Heritage Trails}

Embrio perkembangan heritage trails di Kota Bandung dapat dikatakan berawal dari buku Bandung and Beyond yang ditulis oleh Gottfried Roelcke di pertengahan tahun 1990-an. Buku yang diterbitkan oleh Paguyuban Pelestarian Budaya Bandung (Bandung Heritage) ini pada dasarnya merupakan buku panduan wisata (tourist guide book) tentang Kota Bandung dan dataran tinggi sekitarnya. Di dalam buku ini, Roelcke juga menyusun dan memuat 2 rute jalan kaki (walking tour) dengan fitur utama sejumlah bangunan bersejarah di pusat Kota Bandung. Rute pertama mengangkat kawasan pusat Kota Bandung, dimulai di Kilometer 0, Jalan Asia Afrika, Alun-alun, Jalan Banceuy, dan berakhir di Jalan Braga. Sedangkan rute kedua mengangkat kawasan taman, dimulai di sekitar Kawasan Militer, Gedung Sate, Jalan Dago, dan berakhir di ITB.

Walaupun buku itu secara implisit telah memuat rute heritage trails di Kota Bandung, pada praktiknya belum ada operasionalisasi kegiatan tersebut. Baik pihak pemerintah maupun swasta masih berfokus pada kegiatan wisata di Kota Bandung yang bersifat umum, seperti belanja dan kuliner. Hanya beberapa bangunan bersejarah saja yang diangkat sebagai ikon tur di Kota Bandung, seperti Hotel Preanger, Hotel Savoy Homann, Gedung Merdeka, dan Gedung Sate - itu pun terbatas pada bangunan-bangunan kolonial saja, sesuai latar belakang penulis. Padahal, menurut inventarisasi Bandung Heritage tahun 2007, terdapat lebih dari 200 benda cagar budaya di Kota Bandung dari sejumlah latar belakang ras dan etnis berbeda, seperti lokal (Sunda dan Jawa), Tionghoa, dan Arab. Kesimpulannya, belum ada pihak yang secara serius dan kontinu mengangkat pusaka sebagai daya tarik utama kepariwisataan di Bandung.

Pada 2003, sebuah komunitas akar rumput bernama Heritage Walk muncul. Komunitas ini pada dasarnya tertarik dengan arsitektur kolonial dan terinspirasi oleh buku Bandung and Beyond serta fakta banyaknya objek pusaka yang telah berkembang sebagai daya tarik wisata pusaka di negaranegara lain. Dengan berbekal semangat dan idealisme untuk memperkenalkan pusaka Kota Bandung ke masyarakat luas serta mengembangkan potensi wisata pusaka (heritage tourism) di Kota Bandung, komunitas ini memulai kegiatan perdananya, Bandung Historical Walk, pada Oktober 2003. Kegiatan berupa heritage walk itu mengambil rute Kilometer 0, Jalan Asia Afrika, Alun-alun, Jalan Banceuy, 
Jalan Braga, Taman Balai Kota, Kawasan Militer, dan berakhir di menara Gedung Sate. Tur perdana itu diikuti sekitar 16 peserta, yang berasal dari masyarakat luas, melalui promosi yang terbatas melalui Internet. Informasi tentang kegiatan itu pada akhirnya menyebar dan memunculkan permintaan terhadap kegiatan serupa. Pada akhirnya, kegiatan kedua dilaksanakan pada bulan Desember 2003 dengan jumlah peserta yang jauh lebih besar, yaitu 150 orang.

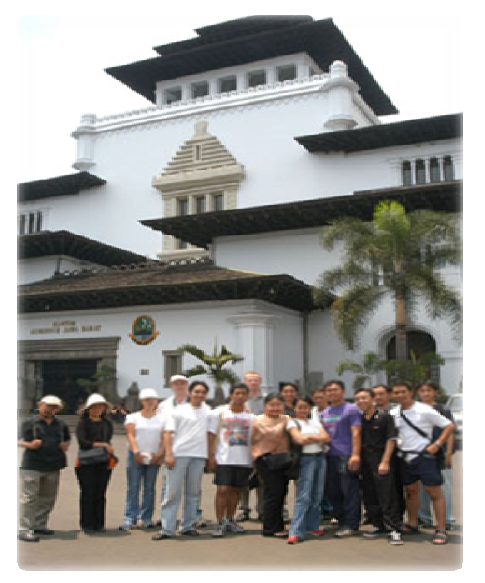

Gambar 2 Bandung Historical Walk (Oktober 2003) adalah heritage trail pertama yang ditujukan untuk masyarakat luas di Kota Bandung, yang diselenggarakan oleh komunitas Bandung Trails

(sumber foto: dokumen pribadi)

Melihat animo masyarakat yang cukup besar, akhirnya kegiatan tersebut mulai rutin diselenggarakan sejak pertengahan 2004. Dengan mengeksplorasi rute dan tema baru, kegiatan heritage walk dilaksanakan antara 3 - 5 kali setahun. Tujuan utamanya tetap menyebarkan kesadaran akan pusaka dan pelestarian kepada masyarakat luas dan bersifat nirlaba. Kegiatan jenis ini dinamai Heritage in Togetherness. Dalam perkembangannya, nama komunitas pun sempat diganti pada tahun 2004 menjadi Bandung Trails, yang tetap digunakan sampai saat ini. Pelaksananya pun berasal dari mantan peserta, atau masyarakat luas, yang bersifat sukarela (volunteer).

Seiring perkembangannya, Bandung Trails mulai dikenal oleh beberapa pengunjung mancanegara di Kota Bandung. Melihat potensi pasar wisatawan mancanegara, pada 2007 Bandung Trails membuka unit usahanya, Bandung Walks. Unit yang berorientasi keuntungan (profit) ini menargetkan wisatawan mancanegara (terutama asal Negeri Belanda) dan institusi-institusi pendidikan. Rute yang ditawarkan adalah Rute Klasik, sama seperti Bandung Historical Walk (Kilometer 0, Jl Asia Afrika, Alun-alun, Jl Braga - apabila menginginkan lebih, rute diperpanjang ke Gedung Sate atau ke tempat-tempat lain sesuai permintaan konsumen).

Dalam perjalanannya selama 7 tahun, Bandung Trails telah mengembangkan sejumlah tema dan rute heritage walk di Bandung, seperti: (1) Bandung Historical Walk - Sejarah Perkembangan Bandung (Kilometer 0 - Jl Asia Afrika - Alun-alun - Jl Braga - Taman Balai Kota - Kawasan Militer - Gedung Sate); (2) Back to the 20s - Sejarah Taman-taman Kolonial (Jl Cisangkuy - Gedung Sate Jl Dago - ITB - Taman Ganesha); (3) Track Balap - Bandung Lautan Api (diadaptasi dari rute yang dikembangkan Bandung Heritage, De Drikleur - Jl Braga - Alun-alun - Kawasan Dewi Sartika Taman Tegallega); (4) Kisah Sang Naga Muda - Kawasan Pecinan (Jl Banceuy - Pasar Baru - Jl Jend. Sudirman - Jl Kelenteng); (5) Urban-dung Legend - Legenda Perkotaan Bandung (Jl Belitung - Jl Aceh - Jl Banda - Jl Bahureksa - Jl Dago); (6) Java Jive - Sejarah Kopi di Dataran Tinggi Parahyangan (Taman Balai Kota - Jl Braga - Jl Banceuy); (7) Locolicious - Sejarah Kereta Api di Dataran Tinggi Parahyangan (Stasiun Pusat Bandung - Cimahi - Padalarang); (8) Farma-o-Rama Kawasan Kesehatan (Jl Cicendo - Jl Cipaganti - Kawasan jalan-jalan nama dokter - RSHS). Selain di 
Kota Bandung, tur pusaka Bandung Trails juga dilakukan ke sejumlah tempat di sekitar Bandung, seperti Sumedang, Ciwidey, Pangalengan, Lembang, dan Goa Pawon, yang juga kaya akan daya tarik wisata pusaka. Selama perjalanannya, kegiatan Heritage in Togetherness telah menarik ribuan peserta, baik dari dalam maupun luar Kota Bandung. Sedangkan Bandung Walks telah menarik sekitar seratus wisatawan mancanegara, terutama asal Belanda.

Dari sisi segmentasi, peserta Heritage in Togetherness dapat digolongkan sebagai berikut: lebih dari 50\% berjenis kelamin wanita, lebih dari 70\% berusia antara 19-30 tahun (lebih dari 40\%-nya berusia 19-22 tahun yang berarti didominasi mahasiswa), dan lebih dari 80\% berdomisili di Bandung. Yang menarik, lebih banyak peserta mendapat informasi dari teman atau anggota keluarga yang lain (mouth to mouth marketing) dan sebagian besar bertujuan untuk menambah wawasan. Kemunculan Bandung Trails pada akhirnya memicu lahirnya komunitas maupun organisasi usaha sejenis, baik yang sifatnya edukatif dan wisata. Sebagian mengambil tema Bandung Tempo Doeloe. Bahkan Bandung Heritage pun kini tampak lebih percaya diri dalam menjalankan kegiatan jalan-jalan bertema pusaka sesuatu yang pada masa-masa sebelumnya tidak dipandang sebagai kegiatan utama terutama oleh sebagian para pendiri dan anggota board. Di satu sisi kemunculan komunitas dan usaha sejenis meningkatkan persaingan, namun di sisi lain hal ini menunjukkan kesadaran akan pusaka mulai meluas. Bahkan di banyak hal lainnya, tema Bandung Tempo Doeloe mulai banyak diterpakan sebagai tema atau konsep, terutama di hotel, restroran, dan buku di Kota Bandung.

\section{Tinjauan Kritis Kondisi Heritage Trails di Kota Bandung}

\section{Proses Perencanaan}

Setelah membandingkan RIPPDA Kota Bandung 2007-2016 dengan teori tentang proses perencanaan secara umum, maka dapat diasumsikan sebagai berikut. Pertama, secara keseluruhan RIPPDA Kota Bandung belum bersifat komprehensif dan integratif. Belum komprehensif artinya belum mengangkat berbagai aspek yang ada di Kota Bandung. Aspek-aspek yang diangkat baru terbatas pada produk wisata, SDM, hubungan antar pihak terkait, dan pasar dan pemasaran. Aspekaspek seperti sosial, ekonomi, politik, psikologi, antropologi, teknologi, dan hal-hal lainnya belum diangkat. Belum integratif artinya belum secara menyeluruh mengaitkan aspek-aspek yang diangkat dalam RIPPDA. Padahal idealnya sebuah proses perencanaan tentang satu sektor yang terkait masyarakat banyak seharusnya mengangkat sebanyak mungkin aspek-aspek terkait dalam masyarakat dan saling menghubungkan satu sama lain. Dalam perencanaan pariwisata pusaka, sangat penting untuk melibatkan semua pihak terkait (stakeholders). Pelibatan pihak-pihak terkait harus sudah dilakukan dari tahap awal. Hal ini dikarenakan pusaka merupakan bagian dari budaya, memiliki skala (dari skala pribadi, lokal, negara, hingga internasional), serta merupakan sebuah pilihan. Oleh karena itu, pelestarian pusaka harus merupakan keputusan yang dihasilkan oleh para pemilik atau pewaris pusaka. Jika para pihak terkait mendukung pelestarian, dapat diasumsikan bahwa ketersediaan sumber daya pusaka untuk dikembangkan sebagai daya tarik akan memiliki keberlanjutan.

Kedua, mengaitkan dengan dimensi waktu RIPPDA Kota Bandung belum memuat data-data dari masa lalu. Padahal idealnya perencanaan melibatkan tiga dimensi waktu; masa lalu, masa kini, dan masa mendatang. Data-data dari masa lalu hingga masa kini dapat dimanfaatkan untuk memproyeksikan prediksi di masa mendatang. Dalam RIPPDA Kota Bandung 2007-2016, analisis masih berpijak pada data-data masa kini yang digunakan untuk memproyeksikan masa depan. Belum dijelaskan secara rinci bagaimana perkembangan objek pusaka sebagai sumber daya di masa lalu hingga berkembang menjadi kondisinya saat ini.

Ketiga, RIPPDA Kota Bandung belum mencerminkan nilai-nilai dan aspirasi yang dianut oleh masyarakat. Padahal idealnya sebuah perencanaan kepariwisataan harus mempertimbangkan aspek masyarakat lokal (host community). Ketika konsep pembangunan bottom-up (sebagian lainnya menggunakan istilah community-based development) menjadi hal yang didorong penggunaannya, hal 
ini menjadi penting. Masyarakat tidak lagi dianggap sebagai objek atau berperan pasif, namun juga bersifat sebagai subyek dan berperan aktif di banyak tingkatan perencanaan.

Keempat, secara umum RIPPDA Kota Bandung masih meninjau sisi supply (pull factor) dalam porsi yang lebih besar dibanding sisi demand (push factor). Sisi supply yang dimaksud mencakup produk wisata, SDM, dan pasar dan pemasaran. Sementara hal-hal menyangkut wisatawan masih sedikit diulas. Padahal idealnya salah satu tujuan perencanaan kepariwisataan adalah meningkatkan kualitas pengalaman wisatawan, di samping meningkatkan kualitas hidup masyarakat setempat serta melestarikan sumber daya kepariwisataan.

\section{Produk Wisata}

Dalam teorinya, Gunn menyatakan bahwa sebuah daya tarik harus diciptakan dan dikelola, artinya suatu objek tidak dapat berfungsi sebagai daya tarik dan tidak bisa dipromosikan sebelum diidentifikasi, dirancang, didirikan, dan dikelola untuk pengunjung. Di Kota Bandung hampir semua objek pusaka belum diciptakan atau dikelola secara khusus, terlebih untuk tujuan kepariwisataan. Objek pusaka di Bandung masih dimiliki oleh perseorangan atau pemerintahan. Pengembangan daya tarik wisata pusaka di Kota Bandung belum sejalan dengan semangat melestarikan objek pusaka di kota ini serta upaya mempertahankan lansekap dan bangunan unik (karakter) Kota Bandung. Penghancuran karakter unik Kota Bandung terus berlangsung, baik dalam skala kecil maupun skala besar di berbagai sudut di Kota Bandung.

\section{Heritage Trails}

Walaupun pariwisata pusaka telah disebutkan sebagai salah satu prioritas pengembangan dan kantong-kantong pariwisata di Kota Bandung telah memuat objek-objek pusaka, kegiatan heritage trails belum secara khusus disebutkan dalam RIPPDA Kota Bandung. Hal ini menunjukkan bahwa pemerintah baru menaruh perhatian terhadap daya tarik wisata secara umum, dan belum menyentuh kegiatan yang lebih spesifik. Pengembangan heritage trails sebagai produk wisata di Bandung tidak dinisiasi oleh pemerintah, namun oleh komunitas akar rumput seperti Bandung Trails. Sedikit banyak, kegiatan heritage trails yang baru muncul pada tahun 2003 di Kota Bandung telah memicu timbulnya komunitas dan organisasi serupa serta mengangkat citra pusaka (tempo doeloe) di masyarakat luas, usaha, dan pemerintah. Pengembangan heritage trails sebagai produk wisata di Kota Bandung telah menciptakan alternatif wisata di Kota Bandung.

\section{SIMPULAN}

Heritage trails sebagai produk wisata di Kota Bandung merupakan fenomena baru yang muncul pada 2003. Kegiatan ini digagas oleh komunitas akar rumput, yang bertujuan untuk mensosialisasikan pusaka dan pelestarian di Kota Bandung. Dalam perkembangannya, kegiatan heritage trails di Kota Bandung telah menarik sebagian kecil masyarakat dan pengunjung di kota ini (niche market). Dengan demikian hal ini memberi inspirasi baik bagi perseorangan, dunia usaha, dan pemerintah. Walaupun wisata pusaka menjadi salah satu komponen penting dalam RIPPDA 20072016, data yang digunakan sebagai bahan analisis masih belum komprehensif, integratif, dan masih menyentuh permukaannya saja. Selain itu, dari sisi perencanaan, dimensi data yang digunakan tidak didasarkan pada data masa lalu namun data kekinian yang dijadikan dasar untuk proyeksi masa depan.

Berdasarkan hal itu, disarankan untuk mempertimbangkan kondisi masa lalu dan masa kini dalam perencanaan heritage trails sebagai produk pariwisata di Kota Bandung yang kemudian dituangkan ke dalam RIPPDA kota. Data yang digunakan juga sebaiknya lebih rinci, mendalam, dan menyeluruh sehingga produk yang dikembangkan lebih sesuai dengan kebutuhan dan keinginan pasar wisatawan dan sesuai dengan kondisi objek pusaka dari sisi supply. 


\section{DAFTAR PUSTAKA}

Drummond, S and Yeoman, I. (2001). Quality Issues in Heritage Visitor Attractions. Oxford: Butterworth-Heinemann.

Galt, S. (1994). Guidelines for Heritage Trails. Parramatta: New South Wales Heritage Office.

Gunn, C and Var, T. (2002). Tourism Planning - Basics, Concepts, Cases. New York: Routledge.

Mason, P. (2003). Tourism Impacts, Planning and Management. Oxford: Elsevier ButterworthHeinemann.

Masyhuri dan Zainuddin, M. (2009): Metodologi Penelitian, Pendekatan Praktis dan Aplikatif. Bandung: Refika Aditama.

Page, J and Connell, J. (2006). Tourism - A Modern Synthesis. London: Thomson Learning.

Pemerintah Kota Bandung. (2006). RIPPDA Kota Bandung. Bandung.

Timothy, J. D. and Boyd, S. W. (2003). Heritage Tourism. Essex: Pearson Education.

Weaver, D. and Lawton, L. (2006). Tourism Management - Third Edition. Australia: John Wiley \& Sons. 